\title{
Stereochemical Investigations of Diastereomeric $N$-[2-(Aryl)-5- methyl-4-oxo-1,3-thiazolidine-3-yl]-pyridine-3-carboxamides by Nuclear Magnetic Resonance Spectroscopy (1D and 2D)
}

\author{
Öznur Demir-Ordu, ${ }^{1}$ Hale Demir-Dündar, ${ }^{2}$ and Sumru Ozkirimli ${ }^{2}$ \\ ${ }^{1}$ Department of Chemistry, Abant İzzet Baysal University, 14030 Bolu, Turkey \\ ${ }^{2}$ Department of Pharmaceutical Chemistry, Istanbul University, 34116 Istanbul, Turkey
}

Correspondence should be addressed to Öznur Demir-Ordu; demirordu@ibu.edu.tr

Received 13 October 2015; Revised 19 November 2015; Accepted 10 December 2015

Academic Editor: Craig J. Eckhardt

Copyright (C) 2015 Öznur Demir-Ordu et al. This is an open access article distributed under the Creative Commons Attribution License, which permits unrestricted use, distribution, and reproduction in any medium, provided the original work is properly cited.

\begin{abstract}
Some new $N$-[2-(aryl)-5-methyl-4-oxo-1,3-thiazolidine-3-yl]-pyridine-3-carboxamides were synthesized and their structures were investigated by IR, NMR $\left({ }^{1} \mathrm{H},{ }^{13} \mathrm{C}\right.$, and $\left.2 \mathrm{D}\right)$, and mass spectra. The presence of $\mathrm{C}-2$ and $\mathrm{C}-5$ stereogenic centers on the thiazolidinone ring resulted in diastereoisomeric pairs. The configurations of two stereogenic centers were assigned based upon ${ }^{1} \mathrm{H}$ NMR analysis of coupling constants and 2D nuclear overhauser enhancement spectroscopy (NOESY) experiment. Resolution of the diastereoisomers was performed by high performance liquid chromatography (HPLC) using a chiral stationary phase.
\end{abstract}

\section{Introduction}

Pyridine-3-carboxamide (nicotinamide), known as vitamin $\mathrm{PP}$ (pellagra protective), is part of the vitamin B group and plays an important role in biological oxidative chemistry. Pyridine-3-carboxamide derivatives have gained attention because of their diverse pharmacological activities, such as cytoprotective [1], antiviral [2], antitumor [3], and anxiolytic [4] activities.

Thiazolidin-4-one derivatives possess versatile biological activities [5], including antifungal [6], antibacterial [7, 8], anticancer $[9,10]$, anti-inflammatory [11-13], analgesic [14], anticonvulsant $[15,16]$, antiviral $[17,18]$, and antidiabetic activities $[19,20]$.

Currently, nearly $50 \%$ of the drugs are in use as racemates. But stereochemical factors generally have important influence on biological activity of the drug molecules. The two enantiomers present in a racemic mixture can possess different biological activities; that is, one enantiomer has therapeutic value; the other enantiomer may be less effective, inactive, or highly toxic [21-27]. Therefore, the identification and separation of stereoisomers are considered to be important. Chiral compounds bearing thiazolidin-4-one ring have also been studied for their stereochemistry. Several studies have been done on these compounds regarding enantiodifferentiation of stereoisomers in the presence of chiral auxiliary [28], separation of enantiomers by chiral HPLC [29, 30], and determination of absolute conformations [31,32].

It is well known that combinations of two or more heterocyclic scaffolds in one molecule can provide a series of compounds with a broad spectrum of biological activity. Here, we combine thiazolidin-4-one and pyridine-3-carboxamide scaffolds together as part of an ongoing project directed towards the design and synthesis of biologically active nitrogen and sulfur containing heterocyclic compounds [33]. Our research focused on stereochemical investigations on diastereomeric $\mathrm{N}$-[2-(aryl)-5-methyl-4-oxo-1,3-thiazolidine-3-yl]-pyridine3 -carboxamides (2a-f) (Figure 1) by one- and two-dimensional NMR techniques. In addition, the analytical chromatographic separation of some derivatives by chiral HPLC has been examined using a chiral column.

\section{Experimental}

2.1. General. $1 \mathrm{D}{ }^{1} \mathrm{H}$ and ${ }^{13} \mathrm{C}$ NMR spectra of all compounds were recorded on a Varian-Unity Inova 500 spectrometer 
TABle $1:{ }^{1} \mathrm{H}$ NMR $(500 \mathrm{MHz})$ data of compounds $\mathbf{2 a - 2} \mathbf{f}$ in DMSO- $d_{6} \cdot{ }^{\mathrm{a}}$

\begin{tabular}{|c|c|c|c|c|}
\hline Entry & C-6 methyl & C-5 methine & C-2 methine & $\mathrm{CO}-\mathrm{NH}$ \\
\hline $2 a$ & $1.55(\mathrm{~d}, J=7.0 \mathrm{~Hz})$ & $\begin{array}{c}4.13(\mathrm{qd}, J=7.0 \mathrm{~Hz}, 0.97 \mathrm{~Hz}) \\
4.23(\mathrm{qd}, J=7.0,1.47 \mathrm{~Hz})^{\mathrm{b}}\end{array}$ & $5.92(\mathrm{~s})$ & $10.94(\mathrm{~s})$ \\
\hline $2 b$ & $\begin{array}{c}1.54(\mathrm{~d}, J=7.0) \\
1.55(\mathrm{~d}, J=6.8 \mathrm{~Hz})\end{array}$ & $\begin{array}{l}4.12(\mathrm{q}, J=6.8 \mathrm{~Hz})^{\mathrm{b}} \\
4.22(\mathrm{q}, J=6.8 \mathrm{~Hz})^{\mathrm{c}}\end{array}$ & $5.90(\mathrm{~s})$ & $\begin{array}{l}10.94(\mathrm{~s}) \\
10.95(\mathrm{~s})\end{array}$ \\
\hline $2 c$ & $\begin{array}{l}1.55(\mathrm{~d}, J=7.3 \mathrm{~Hz}) \\
1.57(\mathrm{~d}, J=7.3 \mathrm{~Hz})\end{array}$ & $\begin{array}{c}4.15(\mathrm{q}, J=6.8 \mathrm{~Hz})^{\mathrm{b}} \\
4.25(\mathrm{qd}, J=6.8,1.47 \mathrm{~Hz})\end{array}$ & $\begin{array}{c}6.01(\mathrm{~d}, J=1.47 \mathrm{~Hz}) \\
6.02(\mathrm{~s})\end{array}$ & $\begin{array}{l}10.99(\mathrm{~s}) \\
11.01(\mathrm{~s})\end{array}$ \\
\hline $2 d$ & $\begin{array}{l}1.53(\mathrm{~d}, J=7.3 \mathrm{~Hz}) \\
1.55(\mathrm{~d}, J=7.3 \mathrm{~Hz})\end{array}$ & $\begin{array}{c}4.10(\mathrm{q}, J=7.3 \mathrm{~Hz}) \\
4.16(\mathrm{qd}, J=7.3,1.47 \mathrm{~Hz})^{\mathrm{b}}\end{array}$ & $\begin{array}{c}5.87(\mathrm{~s}) \\
5.88(\mathrm{~d}, J=1.47 \mathrm{~Hz})\end{array}$ & $10.90(\mathrm{~s})$ \\
\hline $2 e$ & $\begin{array}{c}1.54(\mathrm{~d}, J=7.3) \\
1.55(\mathrm{~d}, J=6.8 \mathrm{~Hz})\end{array}$ & $\begin{array}{c}4.11(\mathrm{q}, J=6.8 \mathrm{~Hz})^{\mathrm{b}} \\
4.18(\mathrm{qd}, J=6.8,1.46 \mathrm{~Hz})\end{array}$ & $\begin{array}{l}5.89(\mathrm{~s}) \\
5.90(\mathrm{~s}) \\
\end{array}$ & $10.97(\mathrm{~s})$ \\
\hline $2 \mathrm{f}$ & $\begin{array}{c}1.48(\mathrm{~d}, J=7.3) \\
1.52(\mathrm{~d}, J=6.8 \mathrm{~Hz})\end{array}$ & $\begin{array}{c}4.10(\mathrm{q}, J=7.0 \mathrm{~Hz})^{\mathrm{b}} \\
4.21(\mathrm{qd}, J=7.0,1.96 \mathrm{~Hz})\end{array}$ & $\begin{array}{c}6.22(\mathrm{~d}, J=1.96 \mathrm{~Hz}) \\
6.26(\mathrm{~s})\end{array}$ & $\begin{array}{l}11.04(\mathrm{~s}) \\
11.05(\mathrm{~s})\end{array}$ \\
\hline
\end{tabular}

${ }^{\mathrm{a}}$ For ${ }^{1} \mathrm{H}$ NMR data of the other protons, see Section 2.

${ }^{\mathrm{b}}$ The signals corresponding to major diastereomer.

${ }^{c}$ Coupling with C-2 methine was observed as a shoulder.<smiles></smiles>

$$
\begin{array}{ll}
\text { 2a, } \mathrm{R}: 4-\mathrm{Cl} & \text { 2d, R: } 4-\mathrm{OCH}_{2} \mathrm{Ph} \\
\text { 2b, R: } 4-\mathrm{Br} & \text { 2e, R: } 3-\mathrm{OCH}_{3} \\
\text { 2c, R: } 4-\mathrm{CF}_{3} & \text { 2f, R: } 2-\mathrm{NO}_{2}
\end{array}
$$

Figure 1: The synthesized compounds, 2a-f.

operating at 499.7 $\mathrm{MHz}$ for ${ }^{1} \mathrm{H}$ and $124.9 \mathrm{MHz}$ for ${ }^{13} \mathrm{C}$, using tetramethylsilane (TMS) as an internal standard. Chemical shifts $(\delta)$ were reported in parts per million (ppm). Spectral widths of 14 and $230 \mathrm{ppm}$ were used in ${ }^{1} \mathrm{H}$ and ${ }^{13} \mathrm{C} \mathrm{NMR}$, respectively. The splitting patterns of ${ }^{1} \mathrm{H}$ NMR were designed as follows: s: singlet, d: doublet, q: quartet, qd: quartet of doublets, dd: doublet of doublets, and m: multiplet. NOESY experiment was performed on a Varian-Mercury VX-400BB (spectrometer frequency: $399.98 \mathrm{MHz}$, temperature: $24^{\circ} \mathrm{C}$, relaxation delay: $2.0 \mathrm{sec}$, acquisition time: $0.15 \mathrm{sec}$, number of increments: the number of points in $\mathrm{t} 1$ : 200, number of points in each FID (t2): 1920, and spectral width: ${ }^{1} \mathrm{H}$ channel; $14 \mathrm{ppm})$. HMBC experiment was performed on a Varian-Unity Inova 500 spectrometer (spectrometer frequency: $499.7 \mathrm{MHz}$, temperature: $30^{\circ} \mathrm{C}$, relaxation delay: $1.0 \mathrm{sec}$, acquisition time: $0.128 \mathrm{sec}, 400$ increments, and spectral width: ${ }^{1} \mathrm{H}$ channel; $14 \mathrm{ppm},{ }^{13} \mathrm{C}$ channel: $\left.230 \mathrm{ppm}\right)$. IR analyses were performed on a Shimadzu IR AffinityI FTIR using $\mathrm{KBr}$ discs; peaks are reported in $\mathrm{cm}^{-1}$. UV analyses were performed on Shimadzu UV-1601; wavelengths are reported in $\mathrm{nm}$. Liquid chromatography analyses were performed on Shimadzu SCL-10AVP with a diode array detector and using Chiralpak AD column (particle size: $5 \mu \mathrm{m}$, column size: $250 \times 4.6 \mathrm{~mm}$ ). Eluent was n-hexane: 2 -propanol $(85: 15)(\mathrm{v}: \mathrm{v})$ with a flow rate of $0.9 \mathrm{~mL} \mathrm{~min}^{-1}$. Reactions were followed by TLC using silica gel $60-\mathrm{F}_{254}$. Elemental analyses were performed on Thermo Finnigan Flash EA 1112 CHNS-932 analyzer. Melting points were recorded using Buchi B-540 melting point apparatus. The mass spectra were obtained using Finnigan LCQ Advantage Max Waters 2695 Alliance Micromass ZQ.

2.1.1. General Procedure for the Preparation of N-[2-(Aryl)-5methyl-4-oxo-1,3-thiazolidine-3-yl]-pyridine-3-carboxamides. To a suspension of $0.01 \mathrm{~mol}$ of aryl $N^{\prime}$-(substituted benzylidene)pyridine-3-carbohydrazide (1a-f) in $30 \mathrm{~mL}$ dry ben zene was added $2.5 \mathrm{~mL}(0.028 \mathrm{~mol})$ of 2-sulfanylpropanoic acid. The mixture was refluxed for 6-18 hours using a DeanStark trap. Excess benzene was evaporated in vacuo. The resulting residue was triturated with $\mathrm{NaHCO}_{3}$ solution until $\mathrm{CO}_{2}$ evolution ceased and was allowed to stand refrigerated until solidification. The solid thus obtained was washed with water, dried, and recrystallized from ethanol.

Some spectral and X-ray crystallographic data of compounds $\mathbf{2 a}, \mathbf{2} \mathbf{b}$, and $\mathbf{2 f}$ were reported regardless of stereochemistry in our previously published articles [34-36].

2.1.2. N-[2-(4-Chlorophenyl)-5-methyl-4-oxo-1,3-thiazolidin-3yl]-pyridine-3-carboxamide (2a). Diastereomer ratio \% (major/ minor): $54: 46 .{ }^{1} \mathrm{H}-\mathrm{NMR}\left(500 \mathrm{MHz}, \mathrm{DMSO}-d_{6}\right) \delta: 7.43-7.47$ (2H, m, phenyl-H); 7.48-7.50 (1H, m, pyridine- $\mathrm{H}) ; 7.52-7.53$ (2H, m, phenyl-H); 8.04-8.09 (1H, m, pyridine- $\mathrm{H}) ; 8.73$ $(1 \mathrm{H}, \mathrm{dd}, J=6.3 \mathrm{~Hz}, 1.4 \mathrm{~Hz}$, pyridine- $\mathrm{H}) ; 8.84,8.85(1 \mathrm{H}, 2 \mathrm{~d}$, $J=2.9 \mathrm{~Hz}, 1.4 \mathrm{~Hz}$, pyridine-H) [35] (for ${ }^{1} \mathrm{H}$ NMR data of other protons see Table 1). ${ }^{13} \mathrm{C}-\mathrm{NMR}(125 \mathrm{MHz})$ (DMSO- $d_{6}$ ) $\delta$ (ppm): $20.6\left(\mathrm{C}-6, \mathrm{CH}_{3}\right) ; 39.8,39.9(\mathrm{C}-5, \mathrm{CH}) ; 60.4,60.6(\mathrm{C}-$ 2, CH); 124.3, 124.4 (C13, CH); 127.9, 128.0 (C9, C); 129.3, 129.4 (C16, 20, CH); 130.4, 130.7 (C17, 19, CH); 134.2, 134.4 (C18, C); 135.9, 136.0 (C14, CH); 137.2, 138.1 (C15, C); 149.1, 149.2 (C10, $\mathrm{CH})$; 153.5, 153.6 (C12, CH); 164.5, 164.6 (C-8, C=O); 172.5, $172.6(\mathrm{C}-4, \mathrm{C}=\mathrm{O})$ (for designations of carbons see Figure 3 ).

2.1.3. N-[2-(4-Bromophenyl)-5-methyl-4-oxo-1,3-thiazolidin-3yl]-pyridine-3-carboxamide (2b). Diastereomer ratio \% (major/ minor): $60: 40 .{ }^{1} \mathrm{H}-\mathrm{NMR}\left(500 \mathrm{MHz}, \mathrm{DMSO}-d_{6}\right) \delta: 7.44-7.46$ 
(2H, m, phenyl-H); 7.49-7.56 (1H, m, pyridine- $\mathrm{H}) ; 7.57-7.60$ (2H, m, phenyl-H); 8.05-8.09 (1H, m, pyridine- $\mathrm{H}) ; 8.72-8.73$ $(1 \mathrm{H}, \mathrm{m}$, pyridine- $\mathrm{H}) ; 8.86,8.87(1 \mathrm{H}, 2 \mathrm{~d}, J=1 \mathrm{~Hz}$, pyridine$\mathrm{H})$ [36] (for ${ }^{1} \mathrm{H}$ NMR data of other protons see Table 1). ${ }^{13} \mathrm{C}-\mathrm{NMR}(125 \mathrm{MHz})\left(\mathrm{DMSO}-d_{6}\right) \delta(\mathrm{ppm}): 20.2\left(\mathrm{CH}_{3}, \mathrm{C}-6\right.$; 60\%), $20.6\left(\mathrm{CH}_{3}, \mathrm{C}-6 ; 40 \%\right) ; 39.7(\mathrm{CH}, \mathrm{C}-5 ; 40 \%), 39.8(\mathrm{CH}$, C-5; 60\%); 60.4 (CH, C-2; 40\%), 60.7 (CH, C-2; 60\%); 122.8 (C, $\mathrm{C} 18 ; 40 \%), 123.1$ (C, C18; 60\%); 124.3 (CH, C13; 40\%), 124.4 (CH, C13; 60\%); 127.8 (C, C9; 60\%), 127.9 (C, C9; 40\%); 130.7 (CH, C16, 20; 40\%), 130.9 (CH, C16, 20; 60\%); 132.2 (CH, C17, 19; 40\%), 132.3 (CH, C17, 19; 60\%); 135.9 (CH, C14; 60\%), 136.0 (CH, C14; 40\%); 137.7 (C, C15; 60\%), 138.6 (C, $\mathrm{C} 15 ; 40 \%) ; 149.1$ (CH, C10; 60\%), $149.2(\mathrm{CH}, \mathrm{C} 10 ; 40 \%) ; 153.6$ $(\mathrm{CH}, \mathrm{C} 12 ; 40 \%), 153.7$ (CH, C12; 60\%); 164.5 (C=O, C-8; 40\%), 164.6 (C=O, C-8; 60\%); 172.6 (C=O, C-4; 40\%), 172.7 $(\mathrm{C}=\mathrm{O}, \mathrm{C}-4 ; 60 \%)$ (for designations of carbons see Figure 3 ).

2.1.4. N-[2-(4-Trifluoromethylphenyl)-5-methyl-4-oxo-1,3-thiazolidin-3-yl]-pyridine-3-carboxamide (2c). Diastereomer ratio \% (major/minor): $53: 47$. White powder (2.78 g, 73\%); mp 170.0-173.1 ${ }^{\circ} \mathrm{C} ;{ }^{1} \mathrm{H}-\mathrm{NMR}\left(500 \mathrm{MHz}, \mathrm{DMSO}-d_{6}\right) \delta: 7.49-7.51$ $(1 \mathrm{H}, \mathrm{m}$, pyridine- $\mathrm{H}) ; 7.72-7.78(4 \mathrm{H}, \mathrm{m}, 2$-phenyl- $\mathrm{H}) ; 8.05-$ $8.10(1 \mathrm{H}, \mathrm{m}$, pyridine- $\mathrm{H}) ; 8.72-8.73(1 \mathrm{H}, \mathrm{m}$, pyridine- $\mathrm{H}) ; 8.85$, $8.88\left(1 \mathrm{H}, 2 \mathrm{~d}, J=2.0 \mathrm{~Hz}\right.$, pyridine-H) (for ${ }^{1} \mathrm{H}$ NMR data of other protons see Table 1$) ;{ }^{13} \mathrm{C}-\mathrm{NMR}\left(100 \mathrm{MHz}, \mathrm{DMSO}-d_{6}\right)$ $\delta: 20.2,20.3\left(\mathrm{C}-6, \mathrm{CH}_{3}\right) ; 38.6,39.2(\mathrm{C}-5, \mathrm{CH}) ; 60.1,60.4(\mathrm{C}-$ 2, $\mathrm{CH}) ; 124.2,124.3(\mathrm{C} 13, \mathrm{CH}) ; 124.6\left(\mathrm{CF}_{3}, \mathrm{q}, J=271 \mathrm{~Hz}\right)$; 126.1, 126.2 (C17, 19, CH); 127.6, 127.7 (C9, C); 129.0, 129.4 (C16, 20, $\mathrm{CH}) ; 129.8$ and $130.0(\mathrm{C} 18, \mathrm{C}, \mathrm{q}, J=32 \mathrm{~Hz}) ; 135.8,135.9$ (C14, CH); 143.1, 144.0 (C15, C); 148.9, 149.0 (C10, CH); 153.5, 153.6 (C12, CH); 164.4, 164.5 (C-8, C=O); 172.5, 172.7 (C-4, $\mathrm{C}=\mathrm{O}$ ) (for designations of carbons see Figure 3); IR $(\mathrm{KBr})$ : $\nu_{\text {max }}=3143,3037,1732,1676,1620,1595,1544$; UV (EtOH): $\lambda_{\text {max }}(\log \varepsilon)=203.2$ (28135), 219.6 (23655), 262.8 (63.68); ESI MS: $m / z=380.08\left([\mathrm{M}-\mathrm{H}]^{-}, 100\right)$; Anal. Calcd. for $\mathrm{C}_{17} \mathrm{H}_{14} \mathrm{~F}_{3} \mathrm{~N}_{3} \mathrm{O}_{2} \mathrm{~S}$ : C, 53.54; H, 3.70; N, 11.02\%. Found: C, 53.75; $\mathrm{H}, 3.92 ; \mathrm{N}, 10.96 \%$.

2.1.5. N-[2-(4-Benzyloxyphenyl)-5-methyl-4-oxo-1,3-thiazolidin3-yl]-pyridine-3-carboxamide (2d). Diastereomer ratio \% (major/minor): $80: 20$. White powder; yield: $3.68 \mathrm{~g}(88 \%)$; mp 140.4-143.5 C; ${ }^{1} \mathrm{H}-\mathrm{NMR}\left(500 \mathrm{MHz}, \mathrm{DMSO}-d_{6}\right) \delta: 5.08$ $\left(2 \mathrm{H}, \quad \mathrm{s}, \mathrm{O}-\mathrm{CH}_{2}-\mathrm{C}_{6} \mathrm{H}_{5}\right) ;$ 6.99-7.02 (2H, m, 2-phenyl-H); 7.31-7.35 (1H, m, pyridine- $\mathrm{H})$; 7.37-7.51 (7H, m, 2-phenyl and $\left.-\mathrm{O}-\mathrm{CH}_{2}-\mathrm{C}_{6} \underline{\mathrm{H}}_{5}\right) ; 8.06-8.09(1 \mathrm{H}, \mathrm{m}$, pyridine- $\mathrm{H}) ; 8.73$ $(1 \mathrm{H}, \mathrm{dd}, J=7.5 \mathrm{~Hz}, 2.0 \mathrm{~Hz}$, pyridine- $\mathrm{H}) ; 8.84,8.86(1 \mathrm{H}, 2 \mathrm{~d}$, $J=2.0 \mathrm{~Hz}$, pyridine-H) (for ${ }^{1} \mathrm{H}$ NMR data of other protons see Table 1); ${ }^{13} \mathrm{C}-\mathrm{NMR}\left(125 \mathrm{MHz}, \mathrm{DMSO}-d_{6}\right) \delta: 20.0\left(\mathrm{CH}_{3}\right.$, C-6; 20\%), $20.8\left(\mathrm{CH}_{3}, \mathrm{C}-6 ; 80 \%\right) ; 39.8(\mathrm{CH}, \mathrm{C}-5 ; 20 \%), 39.9$ $(\mathrm{CH}, \mathrm{C}-5 ; 80 \%) ; 60.8(\mathrm{CH}, \mathrm{C}-2) ; 70.0\left(\mathrm{CH}_{2}, \mathrm{C} 21\right) ; 115.5(\mathrm{C} 17$, 19, $\mathrm{CH}) ; 124.3(\mathrm{CH}, \mathrm{Cl} ;$; 80\%), $124.4(\mathrm{CH}, \mathrm{C} 13 ; 20 \%) ; 128.0$ (C9, C); 128.3 (CH, C24, 26; 80\%), 128.4 (CH, C24, 26; 20\%); $128.6(\mathrm{CH}, \mathrm{C} 25) ; 129.1(\mathrm{CH}, \mathrm{C} 23,27) ; 130.0(\mathrm{CH}, \mathrm{C} 16,20$; 80\%), 130.3 (CH, C16, 20; 20\%); 130.6 (C15, C); $135.9(\mathrm{CH}$, C14; 20\%), 136.0 (CH, C14; 80\%); 137.5 (C, C22; 20\%), 137.6 (C, C22; 80\%); $149.1(\mathrm{CH}, \mathrm{C} 10 ; 20 \%), 149.2(\mathrm{CH}, \mathrm{C} 10 ; 80 \%)$; $153.6(\mathrm{C} 12, \mathrm{CH}) ; 159.6(\mathrm{C} 18, \mathrm{C}) ; 164.5$ (C-8, C=O); 172.6 (C-4, $\mathrm{C}=\mathrm{O}$ ) (for designations of carbons see Figure 5); IR $(\mathrm{KBr})$ : $\nu_{\max }=3473,3163,3066,1710,1672,1606,1591 ; 1244 . \mathrm{UV}$ $(\mathrm{EtOH}): \lambda_{\max }(\log \varepsilon)=204.8$ (59593), 233.2 (280.89), 266.8 (13560). ESI MS: $m / z=418.10\left([\mathrm{M}-\mathrm{H}]^{-}, 100\right)$; Anal. Calcd. for $\mathrm{C}_{23} \mathrm{H}_{21} \mathrm{~N}_{3} \mathrm{O}_{3} \mathrm{~S}$ : C, 64.47; $\mathrm{H}, 5.17 ; \mathrm{N}, 9.81 \%$. Found: C, 64.63; H, 5.06; N, 9.76\%.

2.1.6. N-[2-(3-Methoxyphenyl)-5-methyl-4-oxo-1,3-thiazolidin3-yl]-piridine-3-carboxamide (2e). Diastereomer ratio \% (major/minor): 73:27. White powder; yield: $2.24 \mathrm{~g}(65 \%)$; mp 101.0-105.0 C; ${ }^{1} \mathrm{H}-\mathrm{NMR}\left(500 \mathrm{MHz}, \mathrm{DMSO}-d_{6}\right) \delta: 3.74$ $\left(3 \mathrm{~h}, \mathrm{~s}, \mathrm{OCH}_{3}\right) ; 6.90-6.93(1 \mathrm{H}, \mathrm{m}, 2$-phenyl-H); 7.02-7.04 (2H, m, 2-phenyl-H); 7.27-7.30 (1H, m, 2-phenyl-H); 7.50 $(1 \mathrm{H}, \mathrm{dd}, J=5.3,4.8 \mathrm{~Hz}$, pyridine $-\mathrm{H}) ; 8.05-8.08(1 \mathrm{H}, \mathrm{m}$, pyridine- $\mathrm{H}) ; 8.72(1 \mathrm{H}, \mathrm{dd}, J=7.8,2.0 \mathrm{~Hz}$, pyridine- $\mathrm{H}) ; 8.85$ (major diastereomer), 8.87 (minor diastereomer) $(1 \mathrm{H}, 2 \mathrm{~d}$, $J=1.9 \mathrm{~Hz}, J=1.9 \mathrm{~Hz}$, pyridine-H) (for ${ }^{1} \mathrm{H} \mathrm{NMR}$ data of other protons see Table 1). ${ }^{13} \mathrm{C}-\mathrm{NMR}\left(125 \mathrm{MHz}, \mathrm{DMSO}-d_{6}\right)$ $\delta: 20.2\left(\mathrm{CH}_{3}, \mathrm{C}-6 ; 73 \%\right), 20.6\left(\mathrm{CH}_{3}, \mathrm{C}-6 ; 27 \%\right) ; 39.8(\mathrm{CH}$, C-5; 27\%), $39.9(\mathrm{CH}, \mathrm{C}-5 ; 73 \%) ; 55.8\left(\mathrm{OCH}_{3}\right) ; 60.9(\mathrm{CH}$, C-2; 27\%), 61.2 (CH, C-2; 73\%); 113.5 (CH, C18; 27\%), 113.8 (CH, C18; 73\%); 115.3 (CH, C16; 27\%), $115.4(\mathrm{CH}, \mathrm{C} 16 ; 73 \%)$; 120.4 (CH, C20; 27\%), 120.8 (CH, C20; 73\%); 124.3 (CH, C13; 27\%), 124.4 (CH, C13; 73\%); 127.9 (C, C9; 73\%), 128.0 (C, C9; 27\%); $130.4(\mathrm{CH}, \mathrm{C19} ; 27 \%), 130.5(\mathrm{CH}, \mathrm{C19} ; 73 \%) ; 136.0(\mathrm{CH}$, C14; 73\%), 136.1 (CH, C14; 27\%); 139.8 (C, C15; 73\%), 140.5 (C, C15; 27\%); $149.1(\mathrm{CH}, \mathrm{C} 10 ; 73 \%), 149.2(\mathrm{CH}, \mathrm{C} 10 ; 27 \%)$; $153.6(\mathrm{CH}, \mathrm{C} 12) ; 160.1$ (C, C17; 73\%), 160.2 (C, C17; 27\%); 164.6 (C-8, C=O); 172.8 (C=O, C-4; 27\%), 172.9 (C=O, C-4; $73 \%$ ) (for designations of carbons see Figure 3); IR (KBr): $\nu_{\max }=3487,3176,3076,1707,1670,1610,1591,1546 ; 1260$; UV $(\mathrm{EtOH}): \lambda_{\max }(\log \varepsilon)=204.0$ (42863), 225.0 (17859), 263.8 (6101); ESI MS: $m / z=342.23\left([\mathrm{M}-\mathrm{H}]^{-}, 100\right)$; Anal. Calcd. for $\mathrm{C}_{17} \mathrm{H}_{17} \mathrm{~N}_{3} \mathrm{O}_{3} \mathrm{~S}$ : C, 56.50, H, 5.30, N, 11.63\%. Found: C, $56.47 ; \mathrm{H}, 4.77 ; \mathrm{N}, 11.50 \%$.

2.1.7. N-[2-(2-Nitrophenyl)-5-methyl-4-oxo-1,3-thiazolidin-3-yl]piridine-3-carboxamide (2f). Diastereomer ratio \% (major/ minor): $52: 48 .{ }^{1} \mathrm{H}-\mathrm{NMR}\left(500 \mathrm{MHz}, \mathrm{DMSO}-d_{6}\right) \quad \delta: 7.51$ $(1 \mathrm{H}, \mathrm{dd}, J=4.8 \mathrm{~Hz}, 4.4 \mathrm{~Hz}$, pyridine- $\mathrm{H}) ; 7.61-7.65(1 \mathrm{H}, \mathrm{m}$, 2-phenyl-H); 7.85-7.90 (2H, m, 2-phenyl-H); 8.04-8.11 (2H, $\mathrm{m}, 2$-phenyl-H and pyridine- $\mathrm{H}) ; 8.73(1 \mathrm{H}, \mathrm{dd}, J=8.3 \mathrm{~Hz}$, $2.0 \mathrm{~Hz}$, pyridine- $\mathrm{H}) ; 8.71,8.79(1 \mathrm{H}, 2 \mathrm{~d}, J=2.4 \mathrm{~Hz}, J=2.4 \mathrm{~Hz}$, pyridine-H) [34] (for ${ }^{1} \mathrm{H}$ NMR data of other protons see Table 1). ${ }^{13} \mathrm{C}-\mathrm{NMR}$ (125 MHz) (DMSO- $\left.d_{6}\right) \delta$ (ppm): 19.0, $21.9\left(\mathrm{C}-6, \mathrm{CH}_{3}\right)$; 37.2, $39.2(\mathrm{C}-5, \mathrm{CH}) ; 56.6,56.7(\mathrm{C}-2, \mathrm{CH})$; 124.2, 124.3 (C13, CH); 125.6, 125.7 (C9, C); 127.9, 128.0 (C17, $\mathrm{CH}) ; 128.3,128.5$ (C20, CH); 130,3, 130.5 (C19, CH); 135.3, 135,4 (C18, CH); 135.5, 135.8 (C15, C); 136.1, 136.2 (C14, CH); 148.1, 148.6 (C16, C); 149.2, 149.3 (C10, CH); 153.5, 153.6 (C12, $\mathrm{CH}) ; 164.7,164.8$ (C-8, C=O); 172.8, $173.2(\mathrm{C}-4, \mathrm{C}=\mathrm{O})$ (for designations of carbons see Figure 3 ).

\section{Results and Discussion}

3.1. Chemistry. Novel compounds $2 \mathbf{a}-\mathbf{f}$ have been synthesized by the reaction of compounds $\mathbf{l a}-\mathbf{f}$ with racemic $( \pm)$ 2-sulfanylpropanoic acid in dry benzene (Figure 2).

The structures of the compounds were determined by microanalysis, IR, ${ }^{1} \mathrm{H}-\mathrm{NMR},{ }^{13} \mathrm{C}-\mathrm{NMR}, \mathrm{HMBC}$, and ESI 


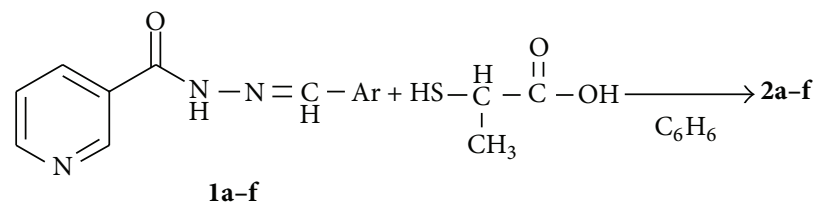

Ar: 4-chlorophenyl, 4-bromophenyl, 4-trifluoromethylphenyl, 4-benzyloxyphenyl, 3methoxyphenyl, 2-nitrophenyl

FIgURE 2: The preparation of compounds 2a-f.

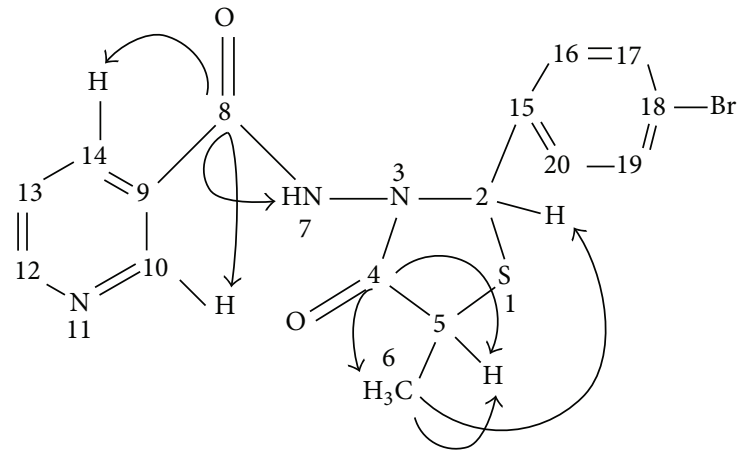

FIgURE 3: Selected HMBC correlations for $\mathbf{2 b}$.

mass spectrometry. IR spectra of $\mathbf{2 a - f}$ showed common characteristic absorption bands at $3142-3176 \mathrm{~cm}^{-1}(\mathrm{NH}), 1707-$ $1732 \mathrm{~cm}^{-1}$ (thiazolidinone $\mathrm{C}=\mathrm{O}$ ), and $1670-1681 \mathrm{~cm}^{-1}(\mathrm{NH}-$ $\mathrm{C}=\mathrm{O}$ ) which provided evidence for the ring closure reaction between $\mathbf{l a}-\mathbf{f}$ and 2-sulfanylpropanoic acid. Disappearance of the peak at $8 \mathrm{ppm}$ corresponding to $\mathrm{N}=\mathrm{CH}$ proton of $\mathbf{1 a}-$ f [37] and the observation of C-2 proton of $\mathbf{2 a - f}$ at 5.88$6.30 \mathrm{ppm}$ in the ${ }^{1} \mathrm{H}-\mathrm{NMR}$ spectra were also taken as the proof of the formation of thiazolidin-4-one ring.

The structure of $\mathbf{2} \mathbf{b}$ was confirmed by the HMBC spectrum in which the correlations of C-8 $\left(\delta_{\mathrm{C}} 164.5,164.6 \mathrm{ppm}\right)$ with $\mathrm{H}-10\left(\delta_{\mathrm{H}} 8.86 \mathrm{ppm}\right), \mathrm{H}-14\left(\delta_{\mathrm{H}} 8.07 \mathrm{ppm}\right)$, and $\mathrm{N}-\mathrm{H}$ $(\mathrm{H}-7)\left(\delta_{\mathrm{H}} 10.94,10.95 \mathrm{ppm}\right) ; \mathrm{C}-4\left(\delta_{\mathrm{C}} 172.6,172.7 \mathrm{ppm}\right)$ with $\mathrm{H}-5\left(\delta_{\mathrm{H}} 4.12,4.22 \mathrm{ppm}\right)$ and $\mathrm{H}-6\left(\delta_{\mathrm{H}} 1.54,1.55 \mathrm{ppm}\right)$; and C-6 $\left(\delta_{\mathrm{C}} 20.6,20.2 \mathrm{ppm}\right)$ with $\mathrm{H}-2\left(\delta_{\mathrm{H}} 5.90 \mathrm{ppm}\right), \mathrm{H}-5\left(\delta_{\mathrm{H}}\right.$ $4.12,4.22 \mathrm{ppm})$, and $\mathrm{H}-6\left(\delta_{\mathrm{H}} 1.54,1.55 \mathrm{ppm}\right)$ enabled definite assignment of $\mathrm{CONH}(\mathrm{C}-8)$ and thiazolidinone $\mathrm{C}=\mathrm{O}(\mathrm{C}-4)$ carbons (Figure 3).

3.2. Stereochemical Investigations. Due to the formation of a new stereocenter at C-2, in principle four stereoisomers were expected to form the following: two enantiomeric $(2 S-$ $5 R / 2 R-5 S, 2 S-5 S / 2 R-5 R)$ and two diastereomeric pairs (2S$5 R / 2 S-5 S, 2 R-5 S / 2 R-5 R$ ) (Figure 4 ). In fact, compounds $2 \mathbf{a}-$ f were obtained as mixtures of unequal composition of two diastereomers which were differentiated by their ${ }^{1} \mathrm{H}$ NMR spectra (Figure 5). It has been observed that the ratios of the major and minor diastereomers calculated from the integration values of the C-5 methine proton signals were $54 \%$ : 46\%, 40\% : 60\%, 47\% : 53\%, 80\% : 20\%, 27\% : $73 \%$, and $48 \%: 52 \%$ for compounds $2 \mathbf{a}-\mathbf{f}$, respectively. ${ }^{13} \mathrm{C}$ signals at C-2, C-4, C-5, and C-6 positions for compounds $2 \mathbf{b}$ and $\mathbf{2 e}$ also appeared as double peaks in the HMBC spectra due to the formation diastereoisomers (see Section 2). Chiral HPLC of compounds $\mathbf{2 b}$ and $\mathbf{2} \mathbf{c}$ on the Chiralpak AD-H column resulted in four peaks (Figure 6) which further proved the presence of four stereoisomers.

For all diastereomeric compounds (Figure 4), it was observed that C-5 methine proton on the thiazolidinone moiety was coupled with C-6 methyl protons and appeared as two quartets (Table 1, Figure 5). Similarly the signal of C-6 methyl protons was coupled with C-5 methine and observed as two doublets for compounds $\mathbf{2 b - 2 f}$. In all of the ${ }^{1} \mathrm{H}$ NMR spectra of compounds $\mathbf{2 a - 2 f}$ (except $\mathbf{2 b}$ ) the higher frequency signals of C-5 methine appeared as a quartet of doublets due to the long-range coupling with the $\mathrm{C}-2$ proton. The two diastereotopic C-2 hydrogens could be observed separately only for compounds $\mathbf{2 c - 2 f}$. Aromatic protons of pyridyl and $\mathrm{C}-2$ aryl rings gave signals between 6.9 and $9.0 \mathrm{ppm}$. In this region some of the aromatic peaks corresponding to two diastereomers could also be observed separately for all compounds (Figure 5). The N-H proton was observed at around $11 \mathrm{ppm}$ as two singlets with unequal integral ratios for compounds $\mathbf{2 b}, \mathbf{2 c}$, and $\mathbf{2 f}$ and only one singlet for $\mathbf{2 a}, \mathbf{2 d}$, and $\mathbf{2 e}$.

We have previously elucidated the stereostructures of some oxazolidine derivatives by NOESY experiment [38-40]. The configurations of the major and minor stereoisomers of thiazolidin-4-one derivatives (2a-2f) were determined by means of ${ }^{1} \mathrm{H}$ NMR and NOESY spectra of compound 2f. The ${ }^{1} \mathrm{H}$ NMR spectrum of $\mathbf{2} \mathbf{f}$ showed that the major diastereomer had its C-5 methine signal (quartet) at a lower frequency $\left(4.10 \mathrm{ppm}, J_{\mathrm{H}-5, \mathrm{CH}_{3}-6}=7.0 \mathrm{~Hz}\right)$ than the signal of the minor component $\left(4.21 \mathrm{ppm}, \mathrm{qd}, \mathrm{J}_{\mathrm{H}-5, \mathrm{CH}_{3}-6}=7.0 \mathrm{~Hz}\right.$ $\left.J_{\mathrm{H}-5, \mathrm{H}-2}: 1.96 \mathrm{~Hz}\right)$. The signal of $\mathrm{C}-2$ proton of compound 2f was observed as two separate signals $(\Delta \delta: 0.04 \mathrm{ppm})$ corresponding to two diastereomers: a singlet at $6.26 \mathrm{ppm}$ for the major diastereomer and a doublet at $6.22 \mathrm{ppm}\left({ }^{4} J_{\mathrm{H}-2, \mathrm{H}-5}=\right.$ $1.96 \mathrm{~Hz}$ ) for the minor diastereomer. The observed longrange coupling constant $\left({ }^{4} J\right)$ of the doublet, which is characteristic of trans protons [41], was consistent with that of the higher frequency quartet of minor diastereomer. Based on these results, the stereochemistry of the minor diastereomer was assigned as $2 S, 5 S$ or $2 R, 5 R$, in which C-2 and C-5 methine protons are trans to each other (Figure 4 ).

NOESY spectrum for compound $2 \mathrm{f}$ was taken in order to further prove that the stereochemistry of the minor and the major diastereomers was $2 S, 5 S / 2 R, 5 R$ and $2 S, 5 R / 2 R$, $5 S$, respectively (Figure 7). Observation of the cross peaks at 


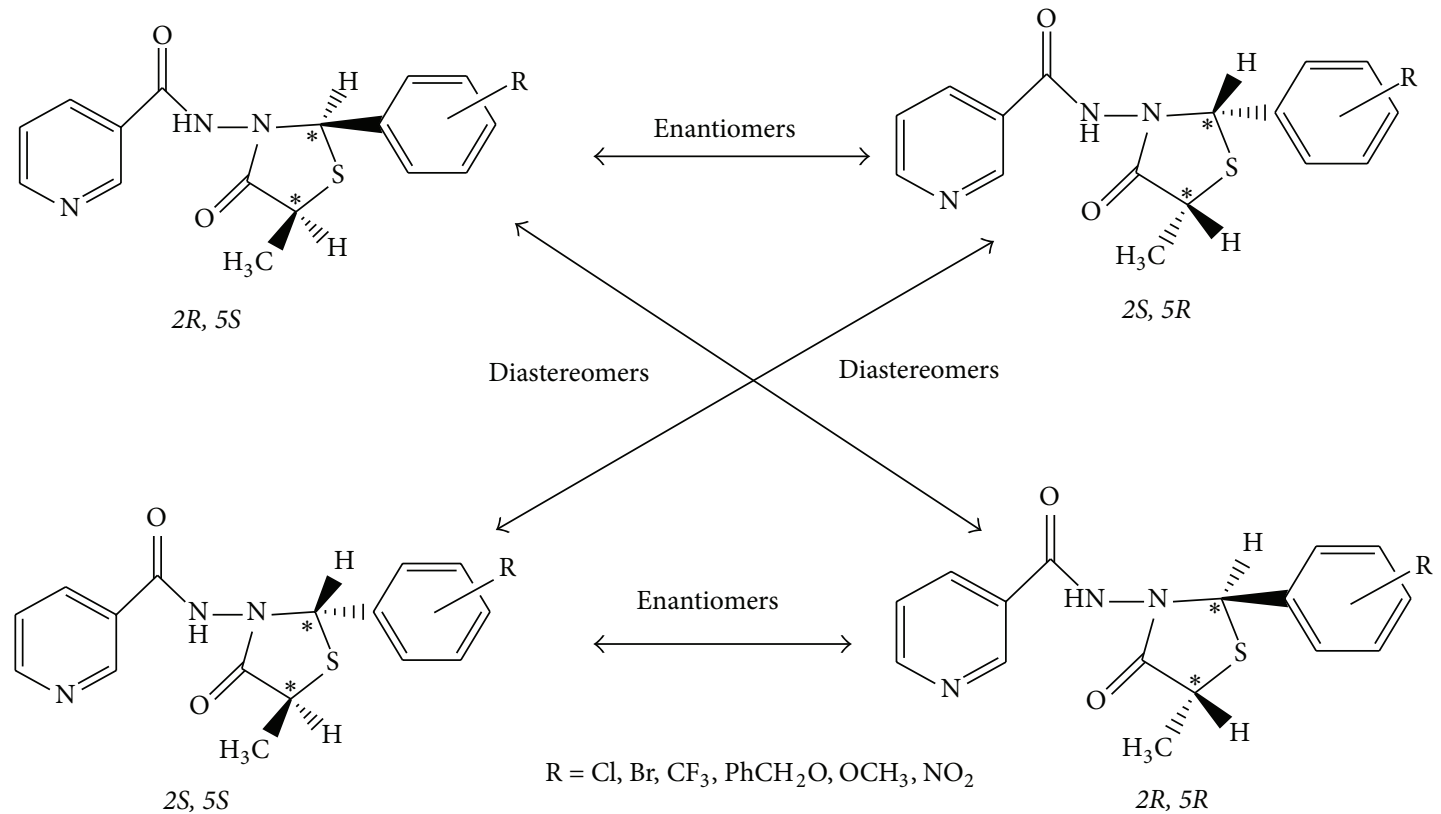

FIGURE 4: The stereoisomers of compounds $\mathbf{2 a - f}$.

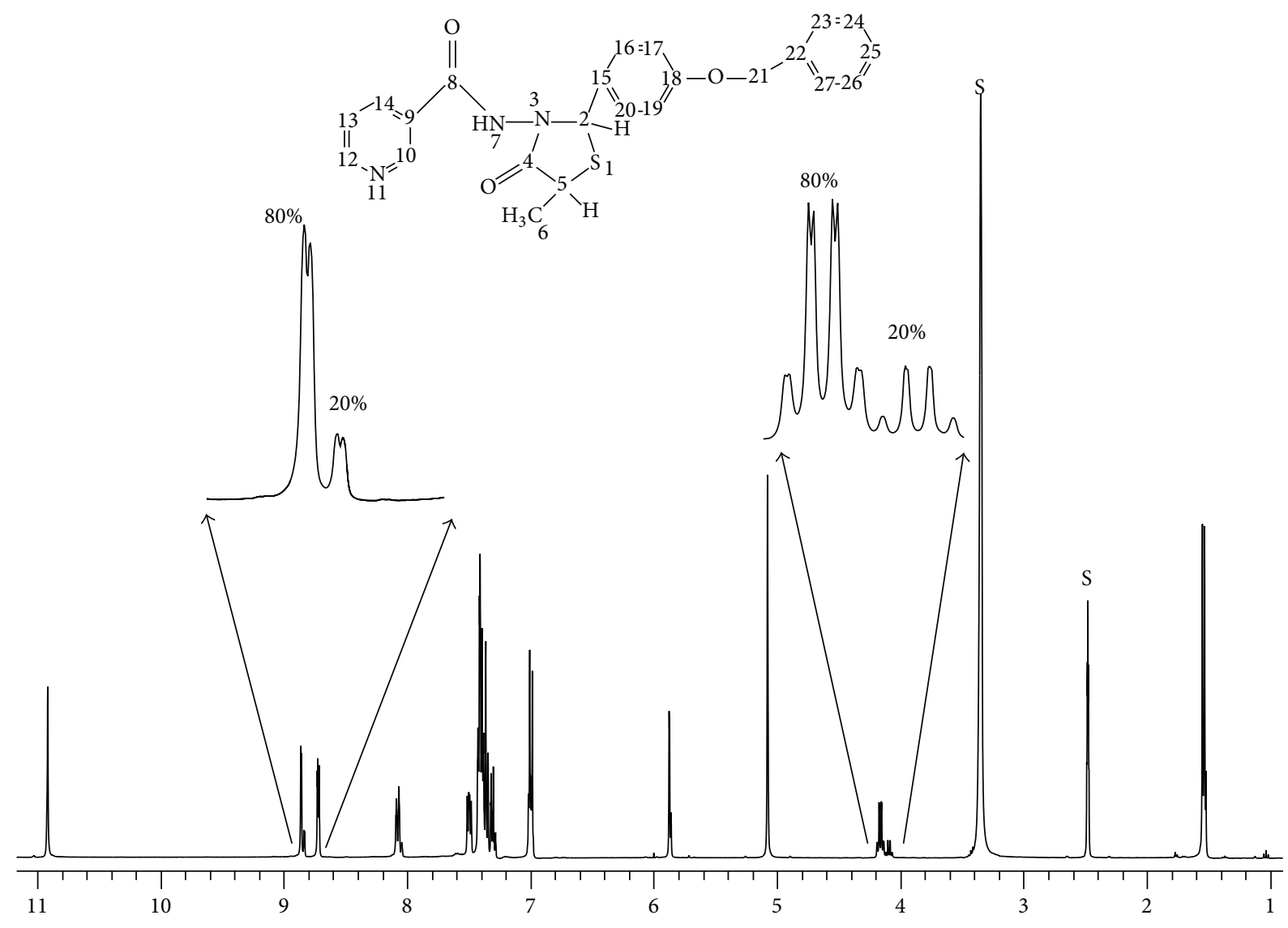

FIgURE 5: $500 \mathrm{MHz}{ }^{1} \mathrm{H}$ NMR spectrum of compound 2d in DMSO- $d_{6}$. S: solvent. 


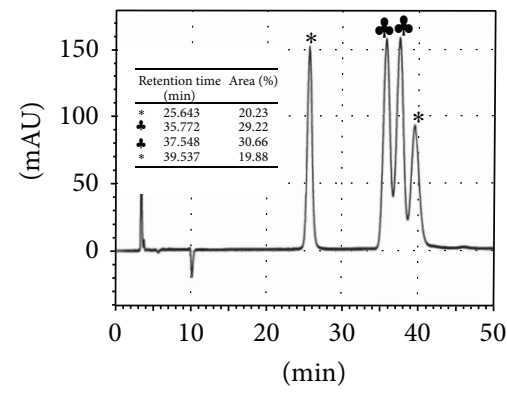

(a)

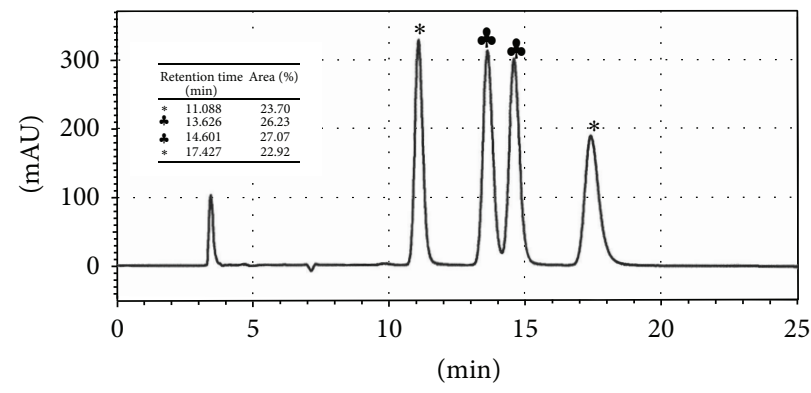

(b)

FIGURE 6: (a) HPLC chromatogram of compound 2b; (b) HPLC chromatogram of compound 2c. Peaks marked with the same sign belong to enantiomers according to their \% areas. Column: Chiralpak AD-H; eluent: n-hexane: 2-propanol (85:15) (v:v); diode array detector.

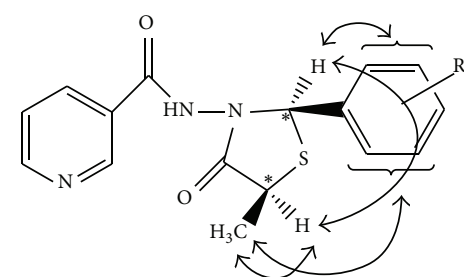

$2 R, 5 S$

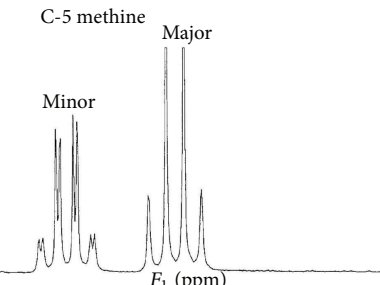

$\begin{array}{llllllll}4.25 & 4.20 & 4.15 & 4.10 & 4.05 & 4.00 & 3.95\end{array}$

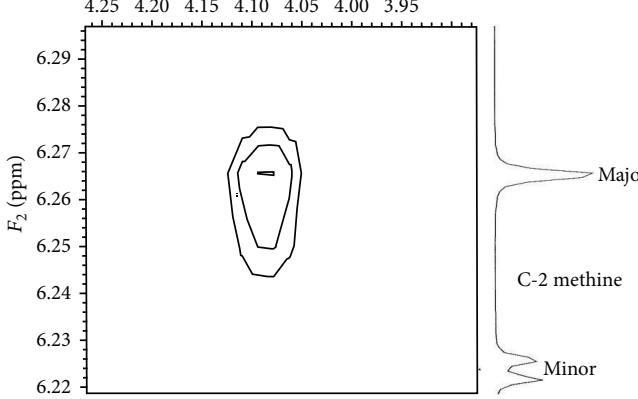

(a)

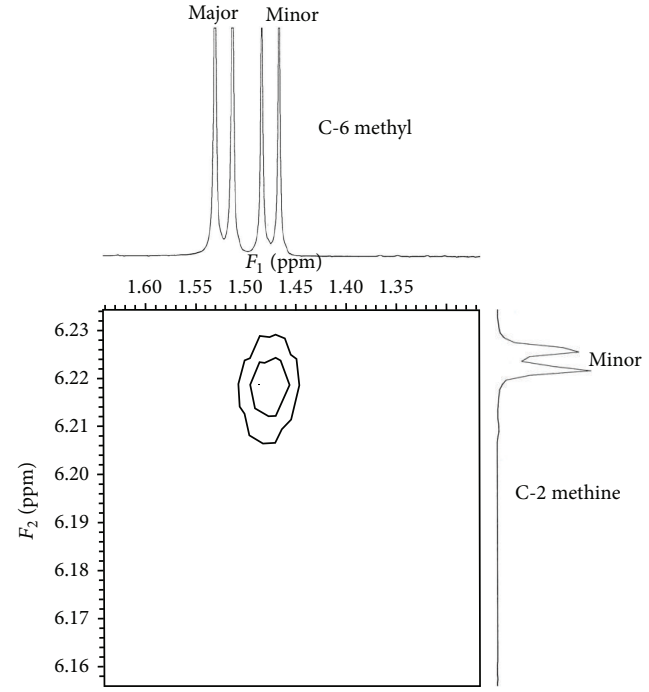

(c)

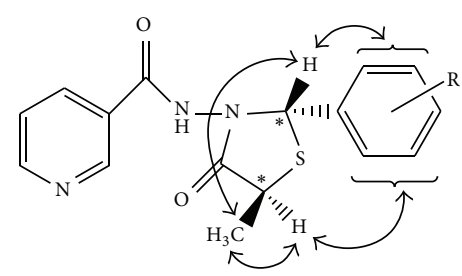

2S, $5 \mathrm{~S}$

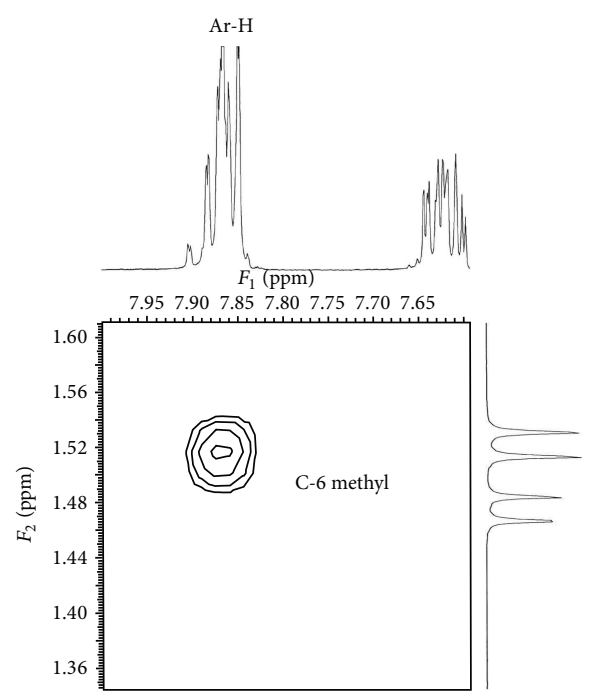

(b)

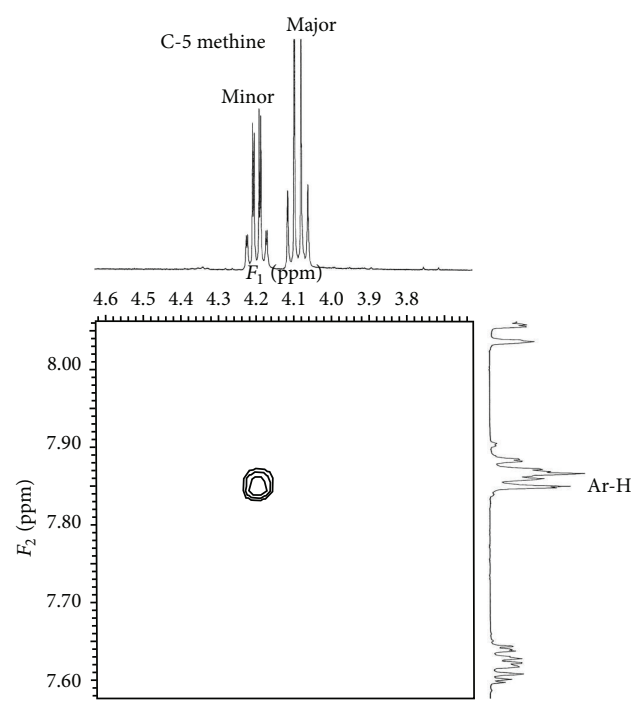

(d)

Figure 7: Selected 2D NOESY correlations for compound $2 \mathbf{f}$ (solvent: DMSO- $d_{6}, 400 \mathrm{MHz}$ ). 
TABLE 2: The configurations of C-2 and C-5 centers of major and minor diastereomers.

\begin{tabular}{lccc}
\hline Compounds & $\begin{array}{c}\text { Diastereomer } \\
\text { ratio, } \%\end{array}$ & $\begin{array}{c}\text { Configurations of C-2 and C-5 } \\
\text { Major } \\
\text { stereoisomer }\end{array}$ & $\begin{array}{c}\text { Minor } \\
\text { stereoisomer }\end{array}$ \\
\hline 2a & $54: 46$ & $2 S, 5 S$ or $2 R, 5 R$ & $2 S, 5 R$ or $2 R, 5 S$ \\
2b & $60: 40$ & $2 S, 5 R$ or $2 R, 5 S$ & $2 S, 5 S$ or $2 R, 5 R$ \\
2c & $53: 47$ & $2 S, 5 R$ or $2 R, 5 S$ & $2 S, 5 S$ or $2 R, 5 R$ \\
2d & $80: 20$ & $2 S, 5 S$ or $2 R, 5 R$ & $2 S, 5 R$ or $2 R, 5 S$ \\
2e & $73: 27$ & $2 S, 5 R$ or $2 R, 5 S$ & $2 S, 5 S$ or $2 R, 5 R$ \\
2f & $52: 48$ & $2 S, 5 R$ or $2 R, 5 S$ & $2 S, 5 S$ or $2 R, 5 R$ \\
\hline
\end{tabular}

$6.26 \mathrm{ppm}$ and $4.10 \mathrm{ppm}$ in 2D NOESY spectrum indicated the spatial proximity of C-2 and C-5 methine hydrogens of the major diastereomer (Figure $7(\mathrm{a})$ ). Cross peaks at $1.52 \mathrm{ppm}$ and $7.86 \mathrm{ppm}$ also revealed that C-6 methyl and the hydrogens of the aryl ring $[42,43]$ of the major diastereomer are in close proximity (Figure $7(b)$ ). These observations were consistent with the $2 R, 5 S$ or $2 S, 5 R$ configurations. Similarly, for the minor diastereomer cross peaks between the signals of C-6 methyl and C-2 methine hydrogens were observed (Figure 7(c)). A NOESY correlation between C-5 methine and aromatic protons (Figure $7(\mathrm{~d})$ ) further confirmed that the configurations of $\mathrm{C}-2$ and $\mathrm{C}-5$ positions of the minor diastereomer were $2 S, 5 S$ or $2 R, 5 R$. Since the spectra of 2a-2f have the feature in common, by analogy, it could be concluded that all the deshielded signals of C-5 methine belong to $2 S, 5 S$ or $2 R, 5 R$ stereoisomer (Table 1 ). Based on these results, the configurations of C- 2 and C- 5 centers of the major and minor diastereomers are given in Table 2.

The diastereomeric isomer ratios of compounds $\mathbf{2 b}$ and $2 c$ obtained by the integration of the ${ }^{1} \mathrm{H}$ NMR signals have been found identical with those obtained by HPLC analysis. Therefore, with the knowledge of the configurations of the C2 and C-5 centers of the major and minor diastereomers of 2b and 2c, the HPLC peaks (Figures 6(a) and 6(b)) marked by "A" could be assigned to $2 S, 5 R$ or $2 R, 5 S$ (major) and the others to $2 S, 5 S$ or $2 R, 5 R$ (minor).

In order to determine the reason of the diastereoselectivity of the synthesis, samples of $\mathbf{2} \mathbf{d}$ and $\mathbf{2 e}$ were recrystallized once again from ethanol and the composition of crystals precipitated first was analyzed by NMR. We have found a different composition for $\mathbf{2} \mathbf{d}$ and $\mathbf{2 e}$. Therefore, the different isomer ratios showed that the obvious diastereoselectivity upon recrystallization from ethanol was due to different solubilities of the diastereomeric isomers in ethanol which was observed previously $[29,30,39,40]$ and not related to any remarkable favorable attack during ring closure. Nevertheless fractional crystallization of the product from ethanol allowed for an easy access to diastereomerically enriched $\mathbf{2 b}, \mathbf{2} \mathbf{d}$, and 2e (Table 2).

\section{Conclusions}

The reaction of aryl $N^{\prime}$-(substituted benzylidene)pyridine3-carbohydrazide with 2-mercaptopropanoic acid produced mixtures of unequal composition of two diastereomeric $N$-[2-(aryl)-5-methyl-4-oxo-1,3-thiazolidine-3-yl]-pyridine3-carboxamide derivatives which were differentiated by ${ }^{1} \mathrm{H}$ NMR spectra. The configurations of C-2 and C-5 stereogenic centers of thiazolidin-4-one ring for the major and the minor diastereomers have been found via one- and twodimensional NMR spectroscopy. Four stereoisomers of compounds $\mathbf{2} \mathbf{b}$ and $\mathbf{2} \mathbf{c}$ were resolved by chiral HPLC.

\section{Conflict of Interests}

The authors declare that there is no conflict of interests regarding the publication of this paper.

\section{Acknowledgment}

This work was supported by the Istanbul University Scientific Research Projects (Project no. T-3691).

\section{References}

[1] E. M. Slominska, A. Yuen, L. Osman, J. Gebicki, M. H. Yacoub, and R. T. Smolenski, "Cytoprotective effects of nicotinamide derivatives in endothelial cells," Nucleosides, Nucleotides and Nucleic Acids, vol. 27, no. 6-7, pp. 863-866, 2008.

[2] A. Moëll, O. Skog, E. Åhlin, O. Korsgren, and G. Frisk, "Antiviral effect of nicotinamide on enterovirus-infected human islets in vitro: effect on virus replication and chemokine secretion," Journal of Medical Virology, vol. 81, no. 6, pp. 1082-1087, 2009.

[3] A. S. Girgis, H. M. Hosni, and F. F. Barsoum, "Novel synthesis of nicotinamide derivatives of cytotoxic properties," Bioorganic and Medicinal Chemistry, vol. 14, no. 13, pp. 4466-4476, 2006.

[4] C. Spanka, R. Glatthar, S. Desrayaud et al., "Piperidyl amides as novel, potent and orally active $\mathrm{mGlu} 5$ receptor antagonists with anxiolytic-like activity," Bioorganic and Medicinal Chemistry Letters, vol. 20, no. 1, pp. 184-188, 2010.

[5] A. K. Jain, A. Vaidya, V. Ravichandran, S. K. Kashaw, and R. K. Agrawal, "Recent developments and biological activities of thiazolidinone derivatives: a review," Bioorganic and Medicinal Chemistry, vol. 20, no. 11, pp. 3378-3395, 2012.

[6] A. P. Liesen, T. M. de Aquino, C. S. Carvalho et al., "Synthesis and evaluation of anti-Toxoplasma gondii and antimicrobial activities of thiosemicarbazides, 4-thiazolidinones and 1,3,4thiadiazoles," European Journal of Medicinal Chemistry, vol. 45, no. 9, pp. 3685-3691, 2010.

[7] K. Omar, A. Geronikaki, P. Zoumpoulakis et al., "Novel 4thiazolidinone derivatives as potential antifungal and antibacterial drugs," Bioorganic \& Medicinal Chemistry, vol. 18, no. 1, pp. 426-432, 2010.

[8] A. Kocabalkanli, Ö. Ates, and G. Ötük, "Synthesis of Mannich bases of some 2,5-disubstituted 4-thiazolidinones and evaluation of their antimicrobial activities," Archiv der Pharmazie, vol. 334, no. 2, pp. 35-39, 2001.

[9] M. M. Kamel, H. I. Ali, M. M. Anwar, N. A. Mohamed, and A. M. Soliman, "Synthesis, antitumor activity and molecular docking study of novel Sulfonamide-Schiff's bases, thiazolidinones, benzothiazinones and their C-nucleoside derivatives," European Journal of Medicinal Chemistry, vol. 45, no. 2, pp. 572580, 2010. 
[10] D. Havrylyuk, L. Mosula, B. Zimenkovsky, O. Vasylenko, A. Gzella, and R. Lesyk, "Synthesis and anticancer activity evaluation of 4-thiazolidinones containing benzothiazole moiety," European Journal of Medicinal Chemistry, vol. 45, no. 11, pp. 5012-5021, 2010.

[11] A. A. Bekhit, H. T. Y. Fahmy, S. A. F. Rostom, and A. E.D. A. Bekhit, "Synthesis and biological evaluation of some thiazolylpyrazole derivatives as dual anti-inflammatory antimicrobial agents," European Journal of Medicinal Chemistry, vol. 45, no. 12, pp. 6027-6038, 2010.

[12] A. Kumar, C. S. Rajput, and S. K. Bhati, "Synthesis of 3-[4'-(pchlorophenyl)-thiazol-2' -yl]-2-[(substituted azetidinone/thiazolidinone)-aminomethyl]-6-bromoquinazolin-4-ones as antiinflammatory agent," Bioorganic and Medicinal Chemistry, vol. 15, no. 8, pp. 3089-3096, 2007.

[13] S. K. Bhati and A. Kumar, "Synthesis of new substituted azetidinoyl and thiazolidinoyl-1,3,4-thiadiazino (6,5-b) indoles as promising anti-inflammatory agents," European Journal of Medicinal Chemistry, vol. 43, no. 11, pp. 2323-2330, 2008.

[14] K. M. Amin, M. M. Kamel, M. M. Anwar, M. Khedr, and Y. N. Syam, "Synthesis, biological evaluation and molecular docking of novel series of spiro $\left[(2 \mathrm{H}, 3 \mathrm{H})\right.$ quinazoline-2, $1^{\prime}$ cyclohexan-4(1H)-one derivatives as anti-inflammatory and analgesic agents," European Journal of Medicinal Chemistry, vol. 45, no. 6, pp. 2117-2131, 2010.

[15] H. Kaur, S. Kumar, P. Vishwakarma, M. Sharma, K. K. Saxena, and A. Kumar, "Synthesis and antipsychotic and anticonvulsant activity of some new substituted oxa/thiadiazolylazetidinonyl/ thiazolidinonylcarbazoles," European Journal of Medicinal Chemistry, vol. 45, no. 7, pp. 2777-2783, 2010.

[16] G. Akula, B. Srinivas, M. Vidyasagar, and S. Kandikonda, "Synthesis of 3-(1H-benzimidazol-2-yl amino)2-phenyl-1,3thiazolidin-4-one as potential CNS depressant," International Journal of PharmTech Research, vol. 3, pp. 360-364, 2011.

[17] V. Ravichandran, A. Jain, K. S. Kumar, H. Rajak, and R. K. Agrawal, "Design, synthesis, and evaluation of thiazolidinone derivatives as antimicrobial and anti-viral agents," Chemical Biology and Drug Design, vol. 78, no. 3, pp. 464-470, 2011.

[18] F. Göktaş, E. Vanderlinden, L. Naesens, N. Cesur, and Z. Cesur, "Microwave assisted synthesis and anti-influenza virus activity of 1-adamantyl substituted $N$-(1-thia-4-azaspiro[4.5]decan-4yl)carboxamide derivatives," Bioorganic and Medicinal Chemistry, vol. 20, no. 24, pp. 7155-7159, 2012.

[19] D. Kini and M. Ghate, "Synthesis and oral hypoglycemic activity of3- [5' -Methyl-2' -aryl-3' -(thiazol-2" -yl amino)thiazolidin-4'one]coumarin derivatives," European Journal of Chemistry, vol. 8, no. 1, pp. 386-390, 2011.

[20] R. MacCari, A. D. Corso, M. Giglio, R. Moschini, U. Mura, and R. Ottan, "In vitro evaluation of 5-arylidene-2-thioxo-4thiazolidinones active as aldose reductase inhibitors," Bioorganic and Medicinal Chemistry Letters, vol. 21, no. 1, pp. 200203, 2011.

[21] J. M. Beale and J. H. Block, Wilson and Gisvold's Textbook of Organic Medicinal and Pharmaceutical Chemistry, Lippincott Williams \& Wilkins, Philadelphia, Pa, USA, 2011.

[22] D. Taşdemir, A. Karaküçük-Iyidoğan, M. Ulaşli, T. Taşkin-Tok, E. E. Oruç-Emre, and H. Bayram, "Synthesis, molecular modeling, and biological evaluation of novel chiral thiosemicarbazone derivatives as potent anticancer agents," Chirality, vol. 27, no. 2, pp. 177-188, 2015.

[23] P. S. Shankar, S. Bigotti, P. Lazzari et al., "Synthesis and cytotoxicity evaluation of diastereoisomers and N-terminal analogues of
tubulysin-U," Tetrahedron Letters, vol. 54, no. 45, pp. 6137-6141, 2013.

[24] J. Bauer, M. Vine, I. Čorić et al., "Impact of stereochemistry on the biological activity of novel oleandomycin derivatives," Bioorganic and Medicinal Chemistry, vol. 20, no. 7, pp. 22742281, 2012.

[25] M. Ohashi, I. Nakagome, J.-I. Kasuga et al., "Design, synthesis and in vitro evaluation of a series of $\alpha$-substituted phenylpropanoic acid PPAR $\gamma$ agonists to further investigate the stereochemistry-activity relationship," Bioorganic and Medicinal Chemistry, vol. 20, no. 21, pp. 6375-6383, 2012.

[26] M. G. Vigorita, R. Ottana, F. Monforte et al., "Chiral 3,3' -(1,2ethanediyl)-bis[2-(3,4-dimethoxyphenyl)-4-thiazolidinones] with anti-inflammatory activity. Part 11: evaluation of COX-2 selectivity and modelling," Bioorganic \& Medicinal Chemistry, vol. 11, no. 6, pp. 999-1006, 2003.

[27] T.-D. Tessema, F. Gassler, Y. Shu, S. Jones, and B. S. Selinsky, "Structure-activity relationships in aminosterol antibiotics: the effect of stereochemistry at the 7-OH group," Bioorganic and Medicinal Chemistry Letters, vol. 23, no. 11, pp. 3377-3381, 2013.

[28] E. D. Gómez, I. Doǧan, M. Yilmaz, Ö. Demir-Ordu, D. Albert, and H. Duddeck, "Atropisomeric 3-aryl-2-oxo-4-oxazolidinones and some thione analogues-enantiodifferentiation and ligand competition in applying the dirhodium method," Chirality, vol. 20, no. 3-4, pp. 344-350, 2008.

[29] S. Erol and İ. Doğan, "Determination of barriers to rotation of axially chiral 5-methyl-2-(o-aryl)imino-3-(o-aryl)thiazolidine4-ones," Chirality, vol. 24, no. 6, pp. 493-498, 2012.

[30] S. Erol and İ. Doğan, "Axially chiral 2-arylimino-3-arylthiazolidine-4-one derivatives: enantiomeric separation and determination of racemization barriers by chiral HPLC, Journal of Organic Chemistry, vol. 72, no. 7, pp. 2494-2500, 2007.

[31] S. Erol and İ. Doğan, "Stereochemical assignments of aldol products of 2-arylimino-3-aryl-thiazolidine-4-ones by ${ }^{1} \mathrm{H} \mathrm{NMR}$," Magnetic Resonance in Chemistry, vol. 50, no. 5, pp. 402-405, 2012.

[32] Ö. Demir-Ordu, E. M. Yilmaz, and I. Doğan, "Determination of the absolute stereochemistry and the activation barriers of thermally interconvertible heterocyclic compounds bearing a naphthyl substituent," Tetrahedron Asymmetry, vol. 16, no. 22, pp. 3752-3761, 2005.

[33] S. Özkırımlı, F. Kazan, and Y. Tunali, "Synthesis, antibacterial and antifungal activities of 3-(1,2,4-triazol-3- yl)-4thiazolidinones," Journal of Enzyme Inhibition and Medicinal Chemistry, vol. 24, no. 2, pp. 447-452, 2009.

[34] M. Akkurt, Í. Çelik, H. Demir, S. Özkrml, and O. Büyükgüngör, " $N$-[5-Methyl-2-(2-nitrophenyl)-4-oxo-1,3-thiazolidin-3yl]pyridine-3-carboxamide monohydrate," Acta Crystallographica Section E, vol. 67, no. 2, pp. o293-o294, 2011.

[35] M. Akkurt, İ. Çelik, H. Demir, S. Özkırıml, and O. Büyükgüngör, "N-[2-(4-chlorophenyl)-5-methyl-4-oxo-1,3-thiazolidin-3yl]pyridine-3-carboxamide," Acta Crystallographica Section E, vol. 67, pp. o745-o746, 2011.

[36] M. Akkurt, İ. Çelik, H. Demir, S. Özkırıml, and O. Büyükgüngör, "N-[2-(4-bromophenyl)-5-methyl-4-oxo-1,3-thiazolidin-3yl]pyridine-3-carboxamide," Acta Crystallographica Section E, vol. 67, pp. o914-o915, 2011.

[37] A. Solankee, P. Solankee, and H. Patel, "Synthesis of some novel hydrazones and their thiazolidine-4-ones," International Journal of Chemical Sciences, vol. 6, pp. 1017-1020, 2008.

[38] Ö. Demir-Ordu and I. Doğan, "Axially chiral N-(o-aryl)-4hydroxy-2-oxazolidinone derivatives from diastereoselective 
reduction of $\mathrm{N}$-(o-aryl)-2,4-oxazolidinediones: thermally interconvertible atropisomers via ring-chain-ring tautomerization," Chirality, vol. 22, no. 7, pp. 641-654, 2010.

[39] Ö. Demir-Ordu and İ. Doğan, "Stereoselective lithiation and alkylation and aldol reactions of chiral 5-methyl-3-(o-aryl)oxazolidinones," Tetrahedron Asymmetry, vol. 21, no. 20, pp. 2455-2464, 2010.

[40] Ö. Demir and İ. Doğan, "Conformational preferences in diastereomeric (5s)-methyl-3-(o-aryl)-2,4-oxazolidinediones," Chirality, vol. 15, no. 3, pp. 242-250, 2003.

[41] V. P. M. Rahman, S. Mukhtar, W. H. Ansari, and G. Lemiere, "Synthesis, stereochemistry and biological activity of some novel long alkyl chain substituted thiazolidin-4-ones and thiazan-4-one from 10-undecenoic acid hydrazide," European Journal of Medicinal Chemistry, vol. 40, no. 2, pp. 173-184, 2005.

[42] K. M. Khan, M. Rasheed, Z. Ullah et al., "Synthesis and in vitro leishmanicidal activity of some hydrazides and their analogues," Bioorganic and Medicinal Chemistry, vol. 11, no. 7, pp. 1381-1387, 2003.

[43] D. Williams and I. Fleming, Spectroscopic Methods in Organic Chemistry, McGraw-Hill Book Company, London, UK, 1989. 

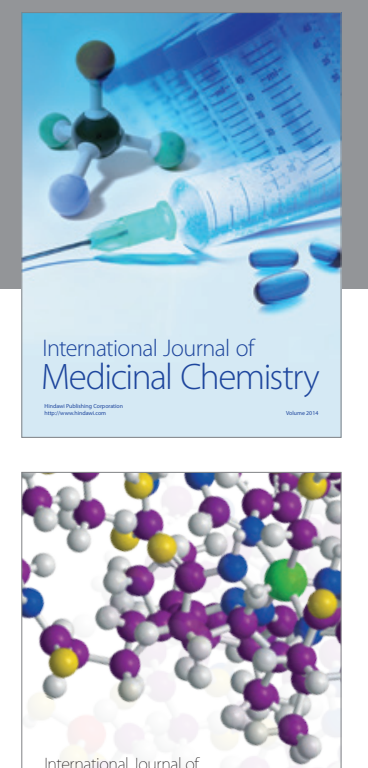

\section{Carbohydrate} Chemistry

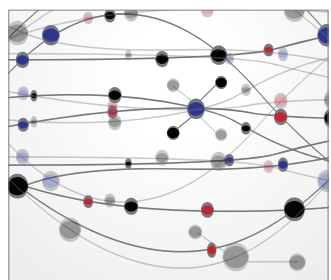

The Scientific World Journal
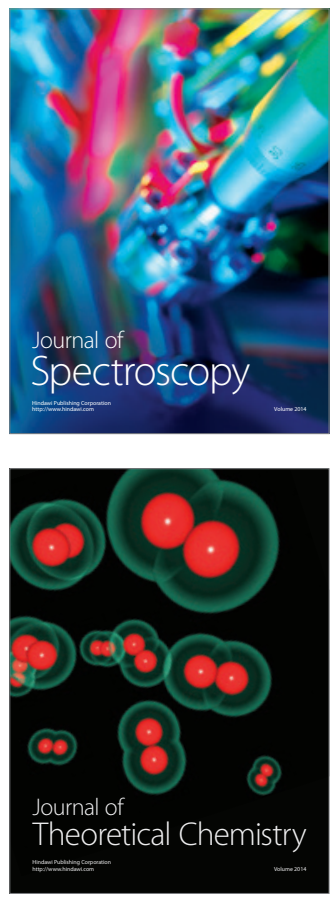
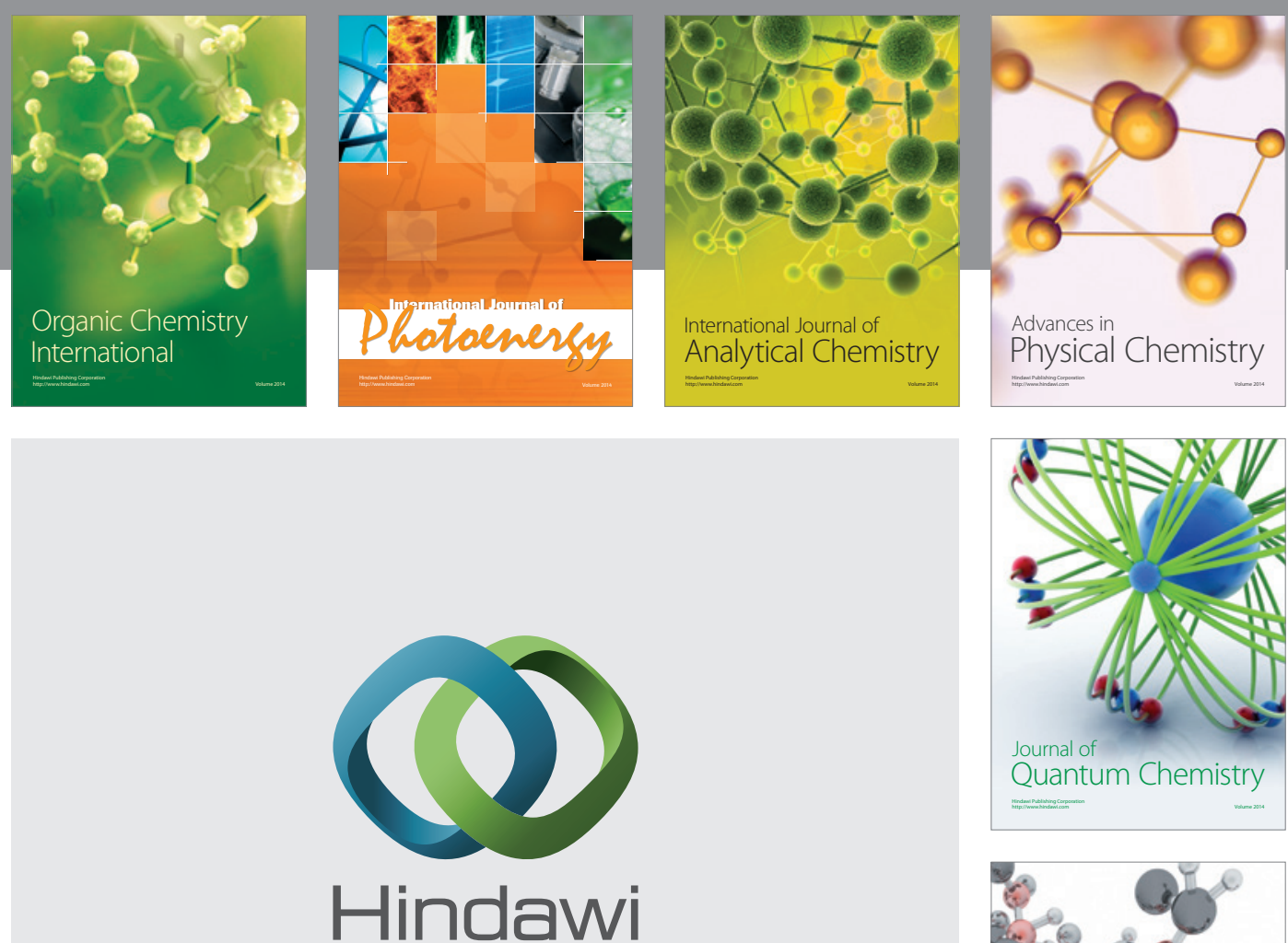

Submit your manuscripts at

http://www.hindawi.com

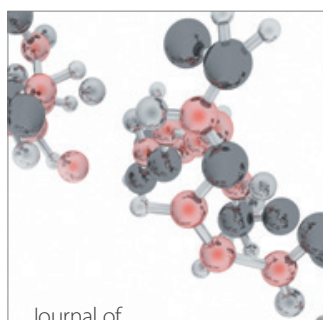

Analytical Methods

in Chemistry

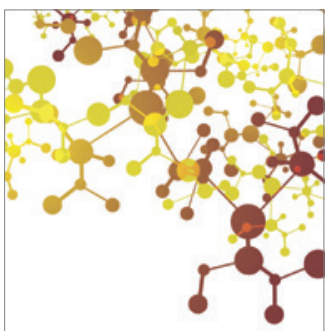

Journal of

Applied Chemistry

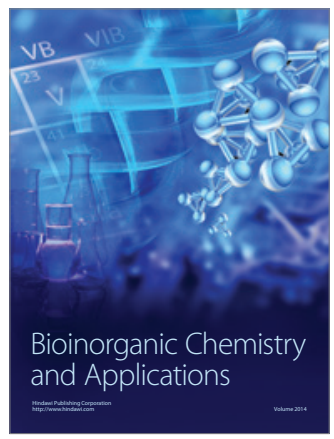

Inorganic Chemistry
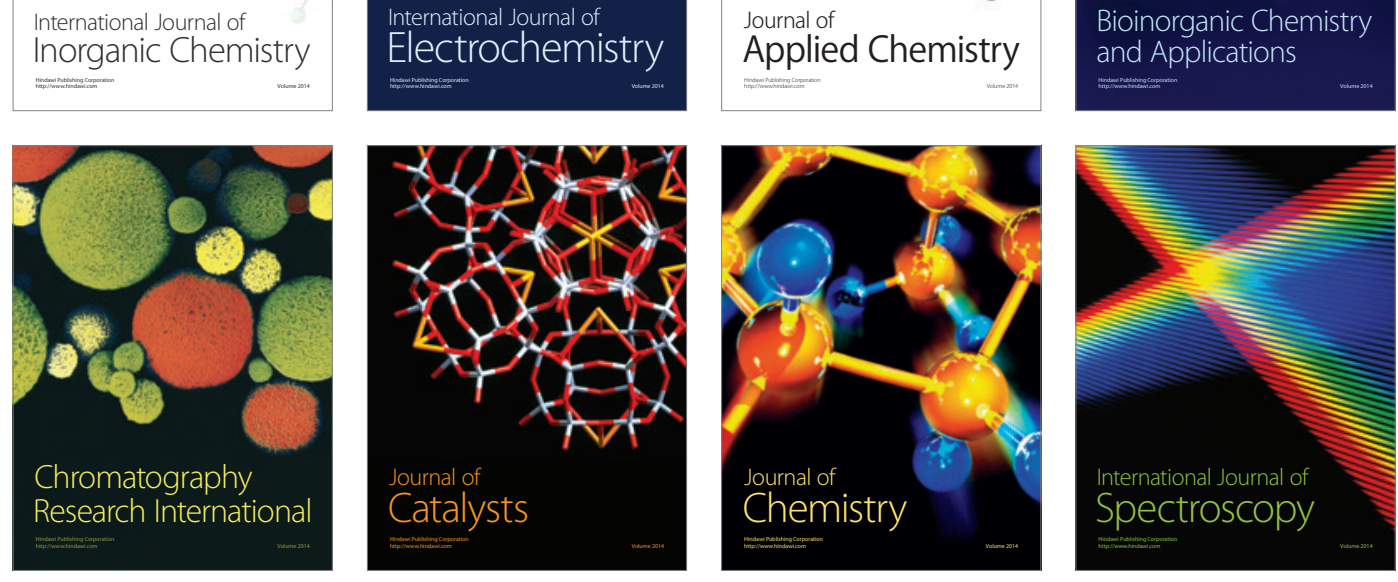